DOI: https://doi.org/10.47405/mjssh.v6i2.648

\begin{tabular}{|c|c|}
\hline$x=$ & Malaysian Journal of Social Sciences and Humanities (MJSSH) \\
\hline Malaysian Journal of & Volume 6, Issue 2, February 2021 \\
\hline (MJ-ssH) & e-ISSN : 2504-8562 \\
\hline & $\begin{array}{l}\text { Journal home page: } \\
\text { www.msocialsciences.com }\end{array}$ \\
\hline
\end{tabular}

\title{
Tahap Amalan Kepimpinan Instruksional Guru Besar dan Hubungannya Dengan Tahap Komitmen Guru
}

\author{
Dayangku Rodzianah Binti Awangku Amin'1, Mohd Izham Bin Mohd Hamzah'1 \\ ${ }^{1}$ Fakulti Pendidikan, Universiti kebangsaan Malaysia (UKM)
}

Correspondence: Dayangku Rodzianah Binti Awangku Amin (ㅁanaamin2002@gmail.com)

\begin{abstract}
Abstrak
Kajian ini dijalankan bertujuan untuk mengenal pasti tahap amalan kepimpinan instruksional guru besar dan tahap komitmen guru. Selain itu, kajian ini juga dilaksanakan untuk mengenal pasti hubungan antara tahap amalan kepimpinan instruksional guru besar dengan komitmen guru sekolah rendah di daerah Beaufort. Kaedah tinjauan kajian dipilih berbentuk kuantitatif yang melibatkan sampel kajian seramai 278 orang guru dari 54 buah sekolah rendah di daerah Beaufort. Instrumen soal selidik yang diedarkan telah diadaptasi dan disesuaikan daripada alat ukuran Principal Intructional Management Rating Scale (PIMRS) dan Collarelli dan Bishop (1990). Objektif kajian diperolehi dengan menganalisa data menggunakan perisian SPSS versi 25 dengan menjalankan analisis deskriptif dan analisis inferensi iaitu ANOVA sehala serta Korelasi Pearson. Hasil kajian ini menunjukkan amalan kepimpinan instruksional guru besar adalah tinggi menurut persepsi guru (Min $=4.39$; $\mathrm{s} . \mathrm{p} .=$ 0.524). Tahap komitmen guru juga adalah sangat tinggi (Min= 4.46; s.p.=0.454). Analisis inferensi ujian ANOVA sehala menunjukkan bahawa terdapat hubungan yang signifikan antara kepimpinan instruksional guru besar dengan jenis sekolah guru di daerah Beaufort $(\mathrm{p}=0.034, \mathrm{p}<0.05)$. Manakala, hasil ujian korelasi Pearson pula menunjukkan hubungan signifikan yang kuat antara tahap amalan kepimpinan instruksional guru besar dengan komitmen guru $(\mathrm{r}=0.921)$. Implikasi kajian ini memberikan input kepada pemimpin sekolah amalan kepimpinan instruksional secara langsung dalam meningkatkan kualiti pengajaran guru. Kesimpulannya, persepsi guru sekolah rendah di daerah Beaufort terhadap amalan kepimpinan instruksional guru besar berada pada tahap yang tinggi. Hasil kajian ini diharap dapat memberikan perspektif yang lebih mendalam mengenai kepimpinan instruksional secara langsung dan kepimpinan intruksional tidak langsung sebagai nilai tambah serta rujukan dalam bidang kepimpinan pendidikan di Malaysia.
\end{abstract}

Kata kunci: kepimpinan, kepimpinan instruksional, komitmen guru, guru besar

\section{Headteachers Instructional Leadership and It Is Relation with Primary Teachers Commitment}

\begin{abstract}
This research was conducted to identify the level of instructional leadership and the level of teachers commitment. Other than that, this study also carried out to show the relationship between the level of instructional leadership practice of headteacher and teachers' commitment in Beaufort district. The research survey method was selected in the form of quantitative involving a study sample of 278 teachers from 54 primary schools in Beaufort district. The distributed questionnaire instruments were
\end{abstract}


adapted and modified from the Principal Instructional Management Rating Scale (PIMRS) and Collarelli and Bishop (1990) measurement tools. The objectives of this study were obtained by analyzing the data using SPSS software version 25 by conducting descriptive analysis and inference analysis, namely one-way ANOVA and Pearson Correlation. The findings of this research showed the instructional leadership practices of headteacher are high according to teachers' perception (Min = 4.39 ; s.d $=0.524)$. The level of teachers' commitment is also high $($ Mean $=4.46$; s.d. $=0.454)$. Oneway ANOVA test analysis showed a significant relationship between headteacher instructional leadership with type of teachers' school in the Beaufort district $(p=0.034, p<0.05)$. Meanwhile, Pearson correlation test showed a strong significant relationship between the level of instructional leadership practice of headteachers with teachers' commitment with a high correlation score $(\mathrm{r}=$ 0.921). The implication of this research provides input to school leaders direct instructional leadership practices on improving the quality of teaching. As a conclusion, the perception of the primary teachers Beaufort district towards headteachers' instructional leadership practices are relatively high. The results of this study expected to provide a deeper perspective on direct instructional leadership and indirect instructional leadership as added value as well as references in the field of leadership education in Malaysia.

Keywords: leadership, instructional leadership, teachers' commitment, headteachers

\section{Pengenalan}

Keberkesanan sesuatu organisasi ditentukan dengan faktor kepimpinan seorang pemimpin. Pemimpin adalah individu yang berupaya membawa satu perubahan yang diperlukan untuk mencapai objektif dan matlamat sesebuah organisasi. Cabaran untuk menggalas tugas serta tanggungjawab seorang guru besar selaku pemimpin sekolah semakin mencabar terutamanya dalam zaman alaf baharu ini dan dunia pendidikan akan sentiasa mengalami perubahan selari dengan isu, perubahan polisi, dasar dan kehendak masyarakat. Perubahan dalam pendidikan sentiasa berlaku dan seorang pemimpin hendaklah sentiasa bersiap siaga dengan sesuatu inovasi menghadapi perubahan tersebut. Seorang pemimpin yang mampu mencetuskan dan menggerak sesuatu perubahan pendidikan dalam organisasi dapat bertahan, berkembang dan terus maju (Mohammad Sani \& Mohd Izham, 2012). Buku Pelan Perancangan Strategik Jabatan Pendidikan Negeri Sabah 2020-2022 telah dilancarkan awal tahun 2020 dan buku ini menggariskan hala tuju dan matlamat Jabatan Pendidikan Negeri Sabah yang perlu dicapai selama 3 tahun. JPN juga telah melancarkan slogan Sabah Hebat: Katakan Tidak Kepada No. 16 yang merangkumi semua aspek pengurusan pendidikan sama ada kurikulum. kokurikulum, sahsiah mahupun aspek pengurusan pentadbiran secara keseluruhannya. Usaha ini sebagai langkah untuk menggerakkan setiap warga pendidikan bekerja dengan lebih proaktif, inovatif dan kreatif untuk menangani isu-isu pendidikan di negeri Sabah dalam membantu mencapai hasrat KPM mewujudkan sekolah yang cemerlang dan mempunyai kemenjadian murid yang berkualiti.

Kepimpinan instruksional atau kepimpinan pengajaran didapati masih relevan untuk diamalkan oleh pemimpin sesebuah organisasi walaupun terdapat pelbagai amalan kepimpinan yang lain. Cabaran untuk menggalas tugas serta tanggungjawab seorang guru besar selaku pemimpin sekolah semakin mencabar terutamanya dalam zaman alaf baharu ini dan dunia pendidikan akan sentiasa mengalami perubahan selari dengan isu, perubahan polisi, dasar dan kehendak masyarakat. Perubahan dalam pendidikan sentiasa berlaku dan seorang pemimpin hendaklah sentiasa bersedia dengan sesuatu inovasi menghadapi perubahan tersebut. Seorang pemimpin yang mampu mencetuskan dan menggerak sesuatu perubahan pendidikan dalam organisasi dapat bertahan, berkembang dan terus maju (Mohammad Sani \& Mohd Izham, 2012). Atribut lain yang menyumbang kepada keberkesanan seorang pemimpin seperti mempunyai kreativiti, perancang yang baik, pelaksana yang konsisten dan penilai yang wajar. Namun perlu ada hubungan yang sinergi antara guru besar dengan para guru untuk memastikan pencapaian visi, misi dan matlamat sekolah tercapai. Matlamat utama adalah menjadikan sekolah sebuah pusat ilmu yang berkualiti dan mempunyai imej yang baik serta iklim persekitaran yang kondusif. 
Tambahan lagi, matlamat utama di setiap kebanyakan sekolah adalah peningkatan prestasi murid yang menjadi tuntutan masyarakat dalam melihat kepada tahap keberkesanan sekolah melalui pentaksiran pembelajaran. Prestasi sesebuah organisasi dipengaruhi dengan faktor komitmen ahlinya, Komitmen dalam sesebuah organisasi adalah antara aspek yang paling banyak dibuat kajian terutamanya dalam bidang pengurusan organisasi (Hackney, 2012). Pekerja yang memberikan komitmen yang tinggi kepada organisasi menunjukkan tingkahlaku yang positif dan kecenderungan untuk memberikan perkhidmatan yang terbaik (Nurharani et al., 2013). Arus perubahan pendidikan masa kini yang sering berubah pada kadar yang agak laju memerlukan guru yang boleh memberikan kerjasama yang baik dan mudah beradaptasi apabila berhadapan dengan perubahan tersebut. Pendidik yang komited juga perlu bersedia untuk menyumbang lebih daripada yang dijangkakan apabila mereka mempunyai efikasi kendiri yang tinggi.

\section{Pernyataan Masalah}

Kepimpinan sering kali dikaitkan dengan keupayaan mempengaruhi atau kuasa seorang pemimpin juga faktor kekayaan dan gaya kepimpinan menjadi aspek penting untuk dikaji oleh para penyelidik. Gaya kepimpinan hendaklah bertepatan dan sesuai dengan matlamat dan tujuan seorang pemimpin dalam mentadbir organisasinya. Sehubungan itu, guru besar instruksional dilihat dapat meningkatkan prestasi sekolah dengan mempengaruhi guru dalam meningkatkan pembelajaran dan pengajaran murid-murid mereka (Mohd Yusri, 2012). Ini dibuktikan dengan kajian-kajian lampau yang menunjukkan hubungan yang tinggi antara tahap amalan kepimpinan instruksional dan komitmen guru. Namun, agenda program instruksional agak sukar dikawal kerana tidak semua pemimpin dapat melaksanakan kesemua dimensi-dimensi kepimpinan instruksional dengan baik apabila wujudnya perbezaan dalam tahap amalan kepimpinan instruksional mereka (Rozila \& Jamalul Lail, 2019).

Guru besar juga perlu berhadapan dengan karenah-karenah guru seperti guru yang tidak hadir bertugas ke sekolah, guru yang selalu datang lewat ke sekolah dan guru tidak mematuhi masa instruksional mengajar masing-masing, sesi pengajaran dan pembelajaran yang tidak mencapai objektif pembelajaran, guru menghadapi isu ketidakpercayaan dan aspek nilai-nilai yang terhad, suasana bilik darjah yang tidak sesuai dan menepati kehendak pengurusan kelas seperti bilik darjah Pembelajaran Abad ke -21 (PAK21) dan kekangan dalam pengurusan sekolah (Rozila \& Jamalul Lail 2019; Junainah 2012). Tambahan lagi pengetua dan guru besar berhadapan dengan masalah untuk mencapai sasaran yang dikehendaki oleh jabatan dan kementerian.

Satu kajian yang mengkaji perbezaan tahap amalan kepimpinan instruksional guru besar dengan komitmen kerja guru sekolah rendah berdasarkan demografi menunjukkan hubungan positif yang lemah dari segi aspek merancang misi dan visi sekolah serta menyampaikan matlamat kurikulum yang kurang berkesan, kekerapan melakukan penilaian dan penyeliaan instruksional yang rendah (Noorshazrina \& Mohd Izham, 2017). Menurut Gurr-Mark et al. (2010), proses instruksional kepimpinan bermaksud pemimpin sekolah melibatkan diri untuk menambahbaikkan instruksional menggunakan pelbagai kaedah seperti membuat pemantauan bilik darjah, penyeliaan seterusnya bimbingan guru atau coaching dan intervensi pengajaran secara langsung.

Hasil dapatan kajian Hassenflug (2013) juga menunjukkan terdapat pemimpin yang kurang pengetahuan tentang amalan kepimpinan instruksional dan pengurusan masa yang lemah. Mereka banyak menggunakan masa pengurusan mereka dengan menghadiri mesyuarat, temu janji, mengurus hal ibu bapa dan masyarakat berbanding memberikan lebih tumpuan dalam peningkatan pembelajaran dan pembangunan kurikulum di sekolah. Ketidakhadiran guru besar di sekolah menyebabkan kurangnya pemantauan dan penilaian terhadap sesi pengajaran dan pembelajaran guru di dalam kelas. Kajian Lokman et al. (2013) juga mendapati pemimpin sekolah tidak begitu mementingkan kepada bahagian penilaian dan pemantauan guru semasa melakukan aktiviti di dalam kelas.

Isu yang seterusnya adalah pemimpin perlu membentuk dan menggalakkan iklim sekolah yang lebih kondusif kerana kajian mendapati dimensi ini mempunyai hubungan yang sederhana terhadap komitmen. Pemberian insentif yang tidak menjurus ke arah peningkatan profesionalisme, kemahiran 
dan menambah ilmu tidak begitu membantu dalam meningkatkan tahap komitmen guru (Dzulfida et al., 2020). Wujudnya konflik apabila guru besar tidak mengurus peranan dan tugas guru dengan terperinci dan jelas berdasarkan kemampuan, sikap dan keperluan setiap individu sama ada guru atau staf sokongan di sekolah. Keadaan ini boleh menyebabkan proses pengurusan sekolah menjadi tidak teratur dan pelaksanaan aktiviti pendidikan di sekolah akan terjejas. Guru pada masa yang sama akan menghadapi tekanan kerja apabila kerja yang diamanahkan melangkaui kemampuan, minat dan kehendak mereka.

\section{Objektif Kajian:}

i. Mengenal pasti tahap amalan kepimpinan instruksional guru besar mengikut persepsi guru di daerah Beaufort.

ii. Mengenal pasti tahap komitmen guru sekolah rendah di daerah Beaufort.

iii. Menentukan perbezaan tahap amalan kepimpinan instruksional guru besar menurut persepsi guru berdasarkan faktor demografi guru besar (tempoh perkhidmatan, tahap akademik dan jenis sekolah) di daerah Beaufort.

iv. Menentukan perbezaan tahap komitmen guru berdasarkan faktor demografi guru (tempoh perkhidmatan, tahap akademik dan jenis sekolah) di daerah Beaufort.

v. Menentukan hubungan antara amalan kepimpinan instruksional guru besar terhadap komitmen guru sekolah rendah di daerah Beaufort.

\section{Sorotan Literatur}

Tinjauan penyelidikan kajian lepas di Malaysia dan luar negara secara jelas menunjukkan gaya kepimpinan instruksional menjadi elemen utama dalam menyumbang kepada perubahan prestasi sekolah. Gaya kepimpinan ini diserapkan dan dipraktikkan secara menyeluruh dalam pentadbiran pengurusan sekolah di Malaysia (KPM, 2007). Kementerian Pelajaran Malaysia juga mengiktiraf pengetua dan guru besar daripada pemimpin sekolah kepada pemimpin instruksional. Mohd Yusri (2012) menyatakan dalam kajiannya bahawa prestasi dan kecemerlangan sekolah dapat dilonjakkan melalui amalan gaya kepimpinan instruksional apabila guru besar membuat perubahan langkahlangkah dalam pengurusan yang boleh mempengaruhi tingkahlaku para pendidik untuk bertindak dalam memastikan kemenjadian murid berlaku di sekolah.

Pemimpin sekolah bertanggungjawab dalam memastikan pembentukan matlamat sekolah hendaklah berkaitan dengan pencapaian prestasi murid (Hallinger, 2000). Matlamat atau halatuju sekolah seharusnya boleh mencapai kesepakatan dan memberikan inspirasi ke arah merealisasikan matlamat tersebut. Peranan sebagai seorang pemimpin yang mengamalkan kepimpinan instruksional boleh mempengaruhi pencapaian murid secara tidak langsung. Menurut Ralph (1974) dalam Puteri et al. (2016), kepimpinan dalam pendidikan adalah kemampuan dan kesiapsiagaan seorang pemimpin pendidikan yang digunakan untuk mempengaruhi, mendorong, mengajak, menuntun, menggerakkan malah jikalau perlu memaksa kakitangan bawahan untuk bertindak sehingga mencapai tujuan tertentu.

Kebanyakan penyelidik pada era tahun 1980an mempertikaikan tentang kemampuan pengetua atau pemimpin sekolah sebagai pemimpin instruksional. Didapati daripada kajian-kajian lampau, gaya kepimpinan instruksional menjadi model kepimpinan pilihan pemimpin-pemimpin sesebuah organisasi. Pengetua yang mempamerkan kepimpinan instruksional perlu untuk meningkatkan prestasi sekolah (Hallinger, 2003). Kepimpinan instruksional mempengaruhi hasil kualiti sekolah melalui penyusunan struktur sekolah seperti standard akademik, peruntukan masa, kurikulum dengan matlamat sekolah (Hallinger \& Heck 1996; Hallinger, 2003). Manakala Bendikson et al. (2012) menyatakan pemimpin sekolah yang sering mengamalkan gaya kepimpinan instruksional berjaya menghasilkan sekolah yang mempunyai prestasi akademik murid yang lebih tinggi dibandingkan dengan guru besar yang kurang mengamalkan gaya kepimpinan ini. Kenyataan ini disokong melalui kajian Aniza dan Zaidatol (2013) 
di Sekolah Berprestasi Sekolah (SBT) yang menunjukkan amalan instruksional guru besar pada tahap yang tinggi berbanding sekolah berprestasi rendah.

Weber (1996) menerangkan tentang konsep kerjasama yang dipraktikkan oleh guru besar untuk menjalankan pengurusan sekolah seperti perkongsian kepimpinan dan pengurusan sekolah dikalangan guru tanpa mengira kedudukan jawatan yang disandang di sekolah. Kepimpinan instruksional merujuk kepada para pemimpin untuk mencari ikhtiar dalam menyokong dan menggalakkan kumpulan pelaksana bagi memastikan proses pembelajaran mencapai misi sekolah dan berjaya membentuk iklim sekolah yang lebih efektif (Fong \& Mohd Khairuddin, 2018). Wildy dan Dimmock (1998) mengatakan bahawa terdapat banyak kajian di luar negara mengenai kepimpinan instruksional yang berfokus kepada pengajaran menunjukkan bahawa perubahan berlaku dalam pengajaran guru dan pembelajaran murid apabila pemimpin sekolah mengamalkan kemahiran instruksional.

Komitmen kepada organisasi adalah sikap dan tingkah laku yang positif seorang individu terhadap organisasinya. Penyelidikan mengenai komitmen organisasi banyak dikaji dalam penyelidikan sesuatu organisasi menurut Hackney (2012). Guru yang mendapat kepuasan kerja di sekolah adalah guru yang boleh memberikan komitmen yang tinggi. Suasana tempat kerja, perhubungan dengan rakan sekerja dan penghargaan yang diberikan oleh organisasi mendorong ke arah kepuasan kerja individu (Haji Mohd, 2004). Nor Azni (2015) mendapati dalam kajiannya menunjukkan kesan kepimpinan instruksional pengetua terhadap komitmen afektif dan komitmen normatif guru dalam melaksanakan Pentaksiran Berasaskan Sekolah (PBS) secara relatifnya adalah tinggi. Namun didapati tahap komitmen berterusan guru dalam melaksanakan PBS pula adalah rendah.

Guru yang memberikan komitmen tinggi juga menunjukkan kesetiaan terhadap sekolah dan mematuhi harapan yang ditetapkan oleh sekolah, bersikap profesional, mempunyai nilai dan etika kerja yang tinggi (Downs et al., 1998). Menurut Robins dan Thimoty (2008), individu yang meletakkan komitmen terhadap organisasinya akan sentiasa memihak kepada organisasi dan sentiasa berusaha mempertahankan keahliannya untuk kekal dalam organisasi tersebut. Terdapat beberapa faktor yang boleh mempengaruhi komitmen individu terhadap organisasinya. Kajian Mathieu dan Zajac (1990) mendapati pengalaman bekerja untuk tempoh masa yang lama dalam sesebuah organisasi menunjukkan salah satu faktor penentu hubungan positif yang rendah dengan tahap komitmen individu.

Kajian rintis yang dibuat di sebuah sekolah menengah agama swasta menggunakan soal selidik instrumen kepimpinan instruksional (PIMRS) menunjukkan terdapatnya hubungan yang signifikan antara kesemua dimensi-dimensi kepimpinan insruksional pengetua dengan tahap komitmen organisasi. Keberadaan pengetua di sekolah agama awasta ini adalah fungsi yang paling tinggi pengaruhnya terhadap tahap komitmen guru dan penyampaian matlamat sekolah pula berada pada tempat kedua tertinggi (Dzulfida et al., 2020). Hasil kajian Sinnu (2019) mendapati ada hubungan yang signifikan secara positif dan kuat antara kepimpinan instruksional guru besar dengan komitmen guru. Kajian yang dijalankan di sekolah agama bantuan kerajaan menunjukkan guru besar berjaya membentuk persekitaran iklim sekolah yang berkesan bagi memastikan proses pengajaran dan pembelajaran berjalan lancar, dimensi ketiga iaitu membentuk iklim positif adalah tinggi.

\section{Metod Kajian}

\section{Rekabentuk kajian}

Kaedah tinjauan iaitu penyelidikan kuantitatif digunakan dalam kajian ini. Instrumen soal selidik diedarkan untuk mendapatkan data yang dikehendaki. Kesemua data telah dikumpulkan dan telah dianalisis menggunakan perisian SPSS atau Statistical Package for Sosial Studies bagi versi 25. Analisis data diperolehi dengan melaksanakan analisis deskriptif dan analisis inferensi untuk menerangkan profil responden kajian ini. Statistik deskriptif iaitu min dan sisihan piawai telah digunakan untuk menentukan tahap amalan kepimpinan instruksional guru besar dan tahap komitmen guru sekolah rendah di daerah Beaufort. Pengkaji juga telah menggunakan statistik inferensi iaitu Ujian ANOVA sehala untuk menentukan perbezaan tahap amalan kepimpinan instruksional guru besar 
berdasarkan faktor demografi iaitu tempoh perkhidmatan, tahap akademik atau ikhtisas dan jenis atau gred sekolah. Seterusnya Ujian Korelasi Pearson digunakan untuk menentukan hubungan antara keduadua pemboleh ubah.

\section{Populasi dan sampel kajian}

Kajian ini tertumpu pada satu daerah sahaja di Sabah iaitu daerah Beaufort. Terdapat 54 buah sekolah rendah yang terdiri daripada jenis Sekolah Kebangsaan (SK), Sekolah Jenis Kebangsaan (SJK) dan Sekolah Kurang Murid (SKM). Populasi kajian ini adalah seramai 1011 orang guru sekolah rendah (Pejabat Pelajaran Daerah Beaufort, Julai 2020). Kaedah persampelan rawak mudah digunakan untuk memilih responden kajian iaitu seramai 278 orang guru akan dipilih daripada 54 buah sekolah rendah di daerah Beaufort. Maklumat mengenai tahap amalan kepimpinan instruksional guru besar, pengkaji mendapatkan pandangan atau persepsi guru-guru sebagai maklum balas kajian.

\section{Instrumen kajian}

Instrumen soal selidik kajian ini telah diubahsuai daripada instrumen Davarajoo (2012) yang mengadaptasi dan mengubahsuai soal selidik Principal Intructional Management Rating Scale (PIMRS) oleh Hallinger dan Murphy (1987) untuk Bahagian B iaitu bagi mengukur amalan-amalan kepimpinan instruksional guru besar. Item-item dalam Bahagian C iaitu Komitmen Guru diadaptasi dan diubahsuai daripada alat ukuran Collarelli dan Bishop (1990) dalam kajian Davarajoo (2012) untuk mengukur komitmen guru pelatih dan nilai kebolehpercayaan Alpha instrumen ini adalah 0.92. Seterusnya, untuk memenuhi keperluan definisi operasional kajian, item-item untuk mengukur tahap amalan kepimpinan instruksional guru besar adalah sebanyak 50 soalan dan jumlah item-item untuk mengukur tahap komitmen guru adalah sebanyak 37 soalan. Keseluruhan item soalan untuk pembolehubah-pembolehubah dalam kajian ini berjumlah 87 soalan. Kajian tinjauan soal selidik ini telah diedarkan kesemua sekolah-sekolah rendah di daerah Beaufort. Soal selidik ini telah dijana menggunakan borang Google atau Google Form yang mudah diedarkan kepada semua sekolah menggunakan aplikasi Whatsapp dan Telegram.

\section{Kajian rintis}

Sebelum melakukan kajian sebenar, satu kajian rintis telah dijalankan untuk mendapatkan kesahan dan kebolehpercayaan item-item dalam instrumen yang disediakan. Item-item dalam instrumen telah diuji untuk mendapatkan kebolehpercayaan melalui Ujian Cronbach Alpha. Untuk memperoleh kebolehpercayaan dan kesahan item keseluruhan, nilai Alpha dari 0.70 hingga 0.95 adalah nilai yang boleh diterima menurut penentuan nilai Alpha oleh Tarakol dan Rennick (2011). Kajian rintis ini telah dijalankan di daerah Papar iaitu Sekolah Kebangsaan Benoni dan seramai 30 orang responden telah mengambil bahagian dalam kajian rintis tersebut. Instrumen soal selidik bagi pemboleh ubah bebas dan pemboleh ubah bersandar telah diedarkan semasa kajian rintis dan telah dianalisis menggunakan ujian Cronbach Alpha. Hasil ujian menunjukkan bahawa statistik kebolehpercayaan item-item soal selidik tersebut adalah $\alpha=0.988$ iaitu pada tahap kebolehpercayaan yang tinggi.

\section{Hasil Kajian}

Jadual 1 menunjukkan taburan demografi responden. Profil demografi responden menunjukkan kebanyakan responden mempunyai tempoh perkhidmatan lebih dari 21 tahun iaitu seramai 113 orang (40.6\%). Dari segi kelayakan akademik tertinggi responden pula, didapati jumlah majoriti responden menunjukkan mereka mempunyai kelayakan Ijazah Sarjana Muda atau yang setaraf iaitu 228 orang $(82 \%)$. Seterusnya, 208 orang $(74.8 \%)$ responden berkhidmat di Sekolah Kebangsaan (SK) di daerah Beaufort. 
DOI: https://doi.org/10.47405/mjssh.v6i2.648

Jadual 1: Profil demografi responden

\begin{tabular}{llcc}
\hline \multicolumn{1}{c}{ Profil } & Kekerapan & Peratus (\%) \\
\hline Tempoh Perkhidmatan & Kurang dari 5 tahun & 20 & 7.2 \\
& 6 -10 tahun & 40 & 14.4 \\
& $11-15$ tahun & 64 & 23.0 \\
& 16-20 tahun & 41 & 14.7 \\
& Lebih 21 tahun & 113 & 40.6 \\
Tahap Akademik/Ikhtisas & Sijil Perguruan & 7 & \\
(yang tertinggi) & STPM & 2 & 2.5 \\
& Diploma Perguruan & 23 & 0.7 \\
& Ijazah Sarjan Muda Pendidikan & 228 & 8.3 \\
& (atau yang setaraf) & & 82.0 \\
& Ijazah Sarjana Pendidikan (atau & & \\
& yang setaraf) & 18 & 6.5 \\
Jenis/Gred Sekolah & Sekolah Kebangsaan & 12 & 4.3 \\
& Sekolah Jenis Kebangsaan & 208 & 74.8 \\
& Sekolah Kurang Murid & 58 & 20.9 \\
\hline
\end{tabular}

\section{Tahap Amalan Kepimpinan Instruksional Guru Besar MenurutPersepsi Guru}

Dapatan kajian ini telah menganalisis skor bagi persoalan kajian yang pertama iaitu apakah tahap amalan kepimpinan instruksional guru besar menurut persepsi guru sekolah rendah di daerah Beaufort. Tahap amalan kepimpinan guru besar yang dikaji dalam kajian ini mempunyai 2 dimensi dan terbahagi kepada 7 sub dimensi. Bahagian 1 iaitu kepimpinan instruksional secara langsung mempunyai 4 sub dimensi iaitu merangka matlamat sekolah, memastikan pembelajaran berkualiti, menggalakkan pembangunan profesional dan membangunkan tanggungjawab secara kolektif. Manakala, dimensi 2, kepimpinan instruksional secara tidak langsung terdiri daripada 3 sub dimensi iaitu memastikan persekitaran pembelajaran yang selamat dan teratur, penyediaan sumber secara strategik dan menyelesaikan masalah yang kompleks. Data analisis kajian akan menunjukkan nilai skor min iaitu nilai yang mewakili keseluruhan data. Manakala sisihan piawai ialah nilai indeks serakan bagi satu taburan skor.

Jadual 2: Tahap Amalan Kepimpinan Instruksional Guru Besar

\begin{tabular}{llccc}
\hline \multicolumn{2}{l}{ Kepimpinan Instruksional Guru Besar } & Min & $\begin{array}{c}\text { Sisihan } \\
\text { Piawai }\end{array}$ & Interpretasi \\
& $\begin{array}{l}\text { Merangka Matlamat Sekolah } \\
\text { Kepimpinan }\end{array}$ & 4.33 & 0.589 & Tinggi \\
$\begin{array}{l}\text { Intruksional Secara } \\
\text { langsung }\end{array}$ & $\begin{array}{l}\text { Memastikan Pembelajaran } \\
\text { Berkualiti } \\
\text { Menggalakkan Pembangunan }\end{array}$ & 4.31 & 0.588 & Tinggi \\
& $\begin{array}{l}\text { Profesional } \\
\text { Membangunkan } \\
\text { Tanggungjawab Secara }\end{array}$ & 4.43 & 0.530 & Tinggi \\
& $\begin{array}{l}\text { Kolektif } \\
\text { Jumlah keseluruhan }\end{array}$ & 4.34 & 0.580 & Tinggi \\
Memastikan Persekitaran & 4.30 & 0.572 & Tinggi \\
$\begin{array}{l}\text { Kepimpinan } \\
\text { Instruksional Secara } \\
\text { Tidak Langsung }\end{array}$ & $\begin{array}{l}\text { Pembelajaran Yang Selamat } \\
\text { dan Teratur }\end{array}$ & 4.50 & 0.529 & Tinggi \\
& $\begin{array}{l}\text { Penyediaan Sumber Secara } \\
\text { Strategik }\end{array}$ & 4.41 & 0.563 & Tinggi \\
Menyelesaikan Masalah & 4.45 & 0.567 & Tinggi \\
Kompleks & 4.40 & 0.553 & Tinggi \\
Jumlah & $\mathbf{4 . 3 9}$ & $\mathbf{0 . 5 2 3}$ & Tinggi \\
\hline
\end{tabular}


Tahap amalan kepimpinan instruksional

Dapatan dalam Jadual 2 menunjukkan skor tahap amalan kepimpinan instruksional guru besar di daerah Beaufort menurut persepsi guru bagi setiap dimensi-dimensi amalan kepimpinan instruksional tersebut. Secara keseluruhannya, tahap amalan kepimpinan instruksional guru besar adalah pada tahap yang tinggi $(\mathrm{Min}=4.39$ : s.p. $=0.523)$. Dimensi kepimpinan instruksional secara tidak langsung menunjukkan nilai $\min$ yang tinggi $($ Min $=4.40$; s.p. $=0.553$ ) berbanding dimensi kepimpinan instruksional secara langsung (Min= 4.30; s.p. $=0.572$ ). Tahap amalan kepimpinan instruksional guru besar menurut persepsi guru menunjukkan sub dimensi memastikan persekitaran pembelajaran yang selamat dan teratur adalah pada kedudukan skor yang paling tinggi $($ Min $=4.50$; s.p. $=0.529)$ dan seterusnya bagi kedudukan skor terendah bagi tahap amalan kepimpinan instruksional guru besar menurut pandangan guru di sekolah rendah daerah Beaufort adalah sub dimensi memastikan pembelajaran berkualiti $(\operatorname{Min}=4.31 ;$ s.p. $=0.588)$.

\section{Tahap Komitmen Guru Daerah Beaufort}

Untuk menjawab persoalan kajian kedua iaitu mengenal pasti apakah tahap komitmen guru di sekolah rendah di daerah Beaufort juga telah diperoleh. Tahap komitmen guru yang dikaji terdiri daripada 4 dimensi iaitu penerimaan matlamat dan nilai organisasi, kesediaan untuk mencapai matlamat, keinginan untuk kekal dalam organisasi dan tahap komitmen dan dedikasi untuk mencapai matlamat organisasi.

Jadual 3: Tahap Komitmen Guru Daerah Beaufort

\begin{tabular}{lccc}
\hline \multicolumn{1}{c}{ Komitmen Guru } & Min & Sisihan Piawai & Interpretasi \\
\hline $\begin{array}{l}\text { Penerimaan Matlamat Dan Nilai } \\
\text { Organisasi }\end{array}$ & 4.45 & 0.503 & Tinggi \\
$\begin{array}{l}\text { Kesediaan Untuk Mencapai Matlamat } \\
\text { Keinginan Untuk Kekal Dalam }\end{array}$ & 4.52 & 0.472 & Tinggi \\
$\begin{array}{l}\text { Organisasi } \\
\text { Tahap Komitmen Dan Dedikasi Untuk } \\
\text { Mencapai Matlamat Organisasi }\end{array}$ & 4.41 & 0.531 & Tinggi \\
\hline Keseluruhan & 4.46 & 0.532 & Tinggi \\
\hline
\end{tabular}

Merujuk kepada Jadual 3, dapatan menunjukkan bahawa tahap komitmen guru sekolah rendah di Beaufort secara keseluruhannya adalah pada tahap yang tinggi $($ Min $=4.46$; s.p. $=0.454)$. Dimensi yang mencatat skor yang tertinggi adalah dimensi kesediaan untuk mencapai matlamat $($ Min $=4.52$; s.p. $=0.472$ ). Kedudukan yang kedua tertinggi pula adalah tahap komitmen dan dedikasi untuk mencapai matlamat organisasi $($ Min $=4.46$, s.p. $=0.532)$. Seterusnya adalah dimensi penerimaan matlamat dan nilai organisasi $(\operatorname{Min}=4.45$; s.p. $=0.503)$. Dimensi yang terendah pula ialah dimensi keinginan untuk kekal dalam organisasi yang menunjukkan skor $($ Min $=4.41$; s.p. $=0.531)$.

\section{Perbezaan Amalan Kepimpinan Instruksional Guru Besar Menurut Persepsi Guru Berdasarkan Faktor Demografi (Tempoh Perkhidmatan, Tahap Akademik dan Jenis Sekolah)}

$H_{o} 1^{1}$ Tidak terdapat perbezaan yang signifikan amalan kepimpinan instruksional guru besar menurut persepsi guru di daerah Beaufort berdasarkan tempoh perkhidmatan. 
Malaysian Journal of Social Sciences and Humanities (MJSSH), Volume 6, Issue 2, (page 135 - 151), 2021

DOI: https://doi.org/10.47405/mjssh.v6i2.648

Jadual 4: Analisis ANOVA amalan kepimpinan instruksional guru besar menurut persepsi Guru berdasarkan tempoh perkhidmatan.

\begin{tabular}{llccccc}
\hline & $\begin{array}{c}\text { Tempoh } \\
\text { Perkhidmatan }\end{array}$ & ss & df & Min Square & F & Sig. \\
\hline Amalan & Dalam kumpulan & 0.738 & 4 & 0.184 & 0.670 & 0.613 \\
Kepimpinan & Antara Kumpulan & 75.179 & 273 & 0.275 & & \\
Instruksional & Jumlah & 75.917 & 277 & & & \\
Guru Besar & & & & & & \\
\hline
\end{tabular}

Analisis ANOVA sehala dijalankan untuk melihat perbezaan yang signifikan antara amalan kepimpinan instruksional guru besar berdasarkan tempoh perkhidmatan guru di sekolah rendah daerah Beaufort. Jadual 4 memaparkan dapatan analisis inferensi menunjukkan nilai signifikan ialah $(\mathrm{p}=$ 0.613 ) melebihi tahap kesignifikan ( $p>0.05$ ). Ini menunjukkan hipotesis $\mathrm{H}_{0} 1^{1}$ gagal ditolak. Keputusan analisis menunjukkan $[\mathrm{F}(\mathrm{df}=4,273, \mathrm{p}>0.05)=0.670]$ iaitu nilai $\mathrm{p}$ adalah tidak signifikan. Dapat dirumuskan bahawa tidak terdapat perbezaan yang signifikan amalan kepimpinan instruksional guru besar menurut persepsi guru di daerah Beaufort berdasarkan tempoh perkhidmatan guru.

$H_{o} 1^{2}$ Tidak terdapat perbezaan yang signifikan amalan kepimpinan instruksional guru besar menurut persepsi guru di daerah Beaufort berdasarkan tahap akademik.

Jadual 5: Analisis ANOVA amalan kepimpinan instruksional guru besar menurut persepsi guru berdasarkan tahap akademik.

\begin{tabular}{llccccc}
\hline & Tahap Akademik & ss & df & $\begin{array}{c}\text { Min } \\
\text { Square }\end{array}$ & F & Sig. \\
\hline Amalan & Dalam kumpulan & 0.507 & 4 & 0.127 & 0.459 & 0.766 \\
Kepimpinan & Antara Kumpulan & 75.410 & 273 & 0.276 & & \\
Instruksional & Jumlah & 75.917 & 277 & & & \\
Guru Besar & & & & & & \\
\hline
\end{tabular}

Jadual 5 menunjukkan hasil ujian ANOVA yang dilancarkan untuk melihat perbezaan yang signifikan antara amalan kepimpinan instruksional guru besar menurut persepsi guru di daerah Beaufort berdasarkan tahap akademik atau ikhtisas. Didapati nilai signifikan ialah $(\mathrm{p}=0.766)$ iaitu nilai skor adalah lebih tinggi daripada tahap signifikan $(\mathrm{p}>0.05)$. Maka, hipotesis $\mathrm{H}_{0} 1^{2}$ tidak berjaya ditolak. Hasil keputusan analisis inferensi $[\mathrm{F}(\mathrm{df}=4,273, \mathrm{p}>0.05)=0.459]$ iaitu nilai $\mathrm{p}$ adalah tidak signifikan. Maka, tidak terdapat perbezaan yang signifikan amalan kepimpinan instruksional guru besar menurut persepsi guru di daerah Beaufort berdasarkan tahap akademik.

$H_{o} 1^{3}$ Tidak terdapat perbezaan yang signifikan amalan kepimpinan instruksional guru besar menurut persepsi guru di daerah Beaufort berdasarkan jenis sekolah.

Jadual 6: Analisis ANOVA amalan kepimpinan instruksional guru besar menurut persepsi guru berdasarkan jenis sekolah.

\begin{tabular}{llccccc}
\hline & Jenis Sekolah & SS & df & Min Square & F & Sig. \\
\hline Amalan & Dalam kumpulan & 1.843 & 2 & 0.921 & 3.420 & 0.034 \\
Kepimpinan & Antara Kumpulan & 74.074 & 275 & & & \\
Instruksional & Jumlah & 75.917 & 277 & & & \\
Guru Besar & & & & & & \\
\hline
\end{tabular}

Jadual 6 menunjukkan hasil ujian inferensi yang dijalankan untuk melihat perbezaan yang signifikan antara amalan kepimpinan instruksional guru besar menurut persepsi guru di daerah Beaufort berdasarkan jenis atau gred sekolah. Didapati nilai signifikan ialah $(\mathrm{p}=0.034)$ iaitu nilai skor adalah lebih rendah daripada tahap signifikan ( $p>0$.05). Maka, hipotesis $\mathrm{H}_{0} 1^{3}$ berjaya ditolak. Hasil keputusan analisis $[\mathrm{F}(\mathrm{df}=2,275, \mathrm{p}>0.05)=3.420]$ iaitu nilai $\mathrm{p}$ adalah signifikan. Oleh itu, terdapat 
perbezaan yang signifikan amalan kepimpinan instruksional guru besar menurut persepsi guru di daerah Beaufort berdasarkan jenis sekolah.

Jadual 7: Perbandingan amalan kepimpinan instruksional Guru Besar menurut persepsi guru berdasarkan jenis sekolah (Ujian Post-Hoc Tukey)

\begin{tabular}{clccc}
\hline & & $\begin{array}{c}\text { Perbezaan } \\
\text { Min }\end{array}$ & Sisihan & \\
(I) Jenis/Gred Sekolah & (J) Jenis/Gred Sekolah & $(\mathbf{I}-\mathbf{J})$ & Piawai & Sig. \\
\hline Sekolah Kebangsaan & $\begin{array}{l}\text { Sekolah Jenis } \\
\text { Kebangsaan }\end{array}$ & $-0.40138^{*}$ & 0.154 & 0.026 \\
& Sekolah Kurang Murid & -0.03981 & 0.077 & 0.863 \\
Sekolah Jenis & Sekolah Kebangsaan & $0.40138^{*}$ & 0.154 & 0.026 \\
Kebangsaan & Sekolah Kurang Murid & 0.36157 & 0.164 & 0.073 \\
Sekolah Kurang Murid & Sekolah Kebangsaan & 0.03981 & 0.077 & 0.863 \\
& $\begin{array}{l}\text { Sekolah Jenis } \\
\text { Kebangsaan }\end{array}$ & -.36157 & .16459 & 0.073
\end{tabular}

* Perbezaan min adalah signifikan pada tahap 0.05

Ujian ANOVA sehala menunjukkan bahawa terdapat perbezaan yang signifikan amalan kepimpinan instruksional guru besar menurut persepsi guru berdasarkan jenis sekolah. Oleh itu, ujian Post-Hoc Tukey dilancarkan untuk melihat perbandingan nilai skor min setiap kumpulan dalam jenis sekolah terhadap amalan kepimpinan instruksional guru besar. Dapatan kajian dalam jadual 7 menunjukkan terdapat perbezaan yang signifikan bagi amalan kepimpinan guru besar antara jenis Sekolah Kebangsaan dan jenis Sekolah Jenis Kebangsaan iaitu nilai $\mathrm{p}<0.05$. Ini menunjukkan bahawa terdapat perbezaan nilai skor min bagi jenis Sekolah Kebangsaan terhadap jenis Sekolah Jenis Kebangsaan bagi amalan kepimpinan instruksional guru besar menurut persepsi guru. Kemudian, nilai perbezaan min untuk Sekolah Jenis Kebangsaan adalah lebih tinggi berbanding Sekolah Kebangsaan (I-J= 0.40138, p $=00.026$ ). Manakala, nilai perbezaan min Sekolah Jenis Kebangsaan lebih tinggi berbanding Sekolah Kurang Murid $(\mathrm{I}-\mathrm{J}=0.36157, \mathrm{p}=0.073)$, namun tidak terdapat perbezaan yang signifikan. Dapatan menunjukkan persepsi guru yang mengajar di Sekolah Jenis Kebangsaan terhadap amalan kepimpinan guru besar adalah lebih tinggi berbanding Sekolah Kebangsaan dan diikuti oleh Sekolah Kurang Murid.

\section{Perbezaan Tahap Komitmen Guru Berdasarkan Faktor Demografi (Tempoh Perkhidmatan, Tahap Akademik dan Jenis Sekolah)}

$H_{o} 2^{1}$ Tidak terdapat perbezaan yang signifikan komitmen guru berdasarkan tempoh perkhidmatan.

Jadual 8: Analisis ANOVA komitmen guru berdasarkan tempoh perkhidmatan.

\begin{tabular}{llccccc}
\hline & \multicolumn{1}{c}{$\begin{array}{c}\text { Tempoh } \\
\text { Perkhidmatan }\end{array}$} & SS & df & Min Square & F & Sig. \\
\hline Komitmen & Dalam kumpulan & .480 & 4 & .120 & .578 & .679 \\
Guru & Antara Kumpulan & 56.641 & 273 & .207 & & \\
& Jumlah & 57.121 & 277 & & & \\
\hline
\end{tabular}

Jadual 8 menunjukkan hasil ujian ANOVA yang dijalankan untuk melihat perbezaan yang signifikan antara komitmen guru berdasarkan tempoh perkhidmatan mengajar guru. Didapati nilai signifikan ialah $(p=0.676)$ iaitu nilai skor adalah lebih tinggi daripada tahap signifikan $(p>0.05)$. Maka, hipotesis $\mathrm{H}_{\mathrm{o}} 1^{2}$ tidak berjaya ditolak. Hasil keputusan analisis inferensi $[\mathrm{F}(\mathrm{df}=4,273, \mathrm{p}>0.05)=0.578]$ 
iaitu nilai $\mathrm{p}$ adalah tidak signifikan. Oleh itu, tidak terdapat perbezaan yang signifikan komitmen guru di daerah Beaufort berdasarkan tempoh perkhidmatan.

$H_{o} 2^{2}$ Tidak terdapat perbezaan yang signifikan komitmen guru berdasarkan tahap akademik.

Jadual 9: Analisis ANOVA komitmen guru berdasarkan tahap akademik.

\begin{tabular}{llccccc}
\hline & Tahap Akademik & Ss & df & Min Square & F & Sig. \\
\hline Komitmen & Dalam kumpulan & 0.480 & 4 & 0.120 & 0.578 & 0.679 \\
Guru & Antara Kumpulan & 56.641 & 273 & 0.207 & & \\
& Jumlah & 57.121 & 277 & & & \\
\hline
\end{tabular}

Jadual 9 memaparkan dapatan kajian untuk melihat perbezaan yang signifikan antara komitmen guru berdasarkan tahap akademik atau ikhtisas guru yang tertinggi. Didapati nilai signifikan ialah $(\mathrm{p}=$ 0.679) iaitu nilai skor adalah lebih tinggi daripada tahap signifikan ( $>>0.05)$. Maka, hipotesis $\mathrm{H}_{\mathrm{o}} 1^{2}$ tidak berjaya ditolak. Hasil keputusan analisis inferensi $[\mathrm{F}(\mathrm{df}=4,273, \mathrm{p}>0.05)=0.578]$ iaitu nilai $\mathrm{p}$ adalah tidak signifikan. Oleh itu, tidak terdapat perbezaan yang signifikan komitmen guru di daerah Beaufort berdasarkan tahap akademik.

$H_{o} 2^{3}$ Tidak terdapat perbezaan yang signifikan komitmen guru berdasarkan jenis sekolah.

Jadual 10: Analisis ANOVA komitmen guru berdasarkan jenis sekolah.

\begin{tabular}{llccccc}
\hline & Jenis Sekolah & SS & df & Min Square & F & Sig. \\
\hline Komitmen & Dalam kumpulan & 0.902 & 2 & 0.451 & 2.207 & 0.112 \\
Guru & Antara Kumpulan & 56.219 & 275 & 0.204 & & \\
& Jumlah & 57.121 & 277 & & & \\
\hline
\end{tabular}

Jadual 10 menunjukkan hasil ujian ANOVA yang dibuat untuk melihat perbezaan yang signifikan antara komitmen guru berdasarkan jenis atau gred sekolah. Didapati nilai signifikan ialah $(\mathrm{p}=0.112)$ iaitu nilai skor adalah lebih tinggi daripada tahap signifikan ( $\mathrm{p}>0.05)$. Maka, hipotesis $\mathrm{H}_{\mathrm{o}} \mathrm{l}^{2}$ tidak berjaya ditolak. Hasil keputusan analisis ANOVA sehala $[\mathrm{F}(\mathrm{df}=2,275, \mathrm{p}>0.05)=2.207]$ iaitu nilai $\mathrm{p}$ adalah tidak signifikan. Oleh itu, tidak terdapat perbezaan yang signifikan komitmen guru di daerah Beaufort berdasarkan tahap akademik.

\section{Hubungan Antara Amalan Kepimpinan Instruksional Guru Besar Terhadap Komitmen Guru di Daerah Beaufort}

$H_{o} 3$ Tidak terdapat hubungan yang signifikan antara amalan kepimpinan guru besar dengan komitmen guru sekolah rendah di daerah Beaufort.

Jadual 11: Analisis Korelasi Pearson amalan kepimpinan instruksional guru besar dengan komitmen guru

\begin{tabular}{llcc}
\hline & & $\begin{array}{c}\text { Amalan Kepimpinan } \\
\text { Instruksional Guru Besar }\end{array}$ & $\begin{array}{c}\text { Komitmen } \\
\text { Guru }\end{array}$ \\
\hline Amalan Kepimpinan & Korelasi Pearson & 1 & $0.921^{* *}$ \\
Instruksional & Sig. (2-hujung) & 278 & 0.000 \\
Guru Besar & $\mathrm{N}$ & & 278 \\
& & $0.921^{* *}$ & 1 \\
Komitmen Guru & Korelasi Pearson & 0.000 & 278 \\
& Sig. (2-hujung) & 278 & \\
$* *$ Korelasi adalah signifikan pada tahap 0.01 (2 hujung). & & \\
\hline
\end{tabular}


Jadual 11 menunjukkan dapatan hasil ujian Korelasi Pearson di antara kedua-dua pemboleh ubah yang dikaji iaitu amalan kepimpinan instruksional guru besar dengan komitmen guru. Dapatan kajian menunjukkan terdapatnya hubungan yang sangat kuat $(\mathrm{r}=0.921)$ antara amalan kepimpinan instruksional guru besar dengan komitmen guru. Nilai signifikan adalah $(\mathrm{p}=0.000)$ iaitu lebih rendah daripada tahap signifikan $(\mathrm{p}<0.01)$. Ini menunjukkan terdapat hubungan signifikan yang kuat antara amalan kepimpinan instruksional guru besar dengan komitmen guru. Dapatan kajian membuktikan semakin positif amalan kepimpinan instruksional guru besar, semakin tinggi tahap komitmen guru.

Jadual 12: Hubungan dimensi-dimensi kepimpinan instruksional guru besar dan komitmen guru

\begin{tabular}{llc}
\hline $\begin{array}{l}\text { Dimensi Kepimpinan Instruksional } \\
\text { Guru }\end{array}$ & Komitmen \\
\hline Merangka Matlamat Sekolah & Korelasi Pearson & $0.809^{* *}$ \\
& Sig. (2-hujung) & 0.000 \\
Memastikan Pembelajaran Berkualiti & N & 278 \\
& Korelasi Pearson & $0.810^{* *}$ \\
Menggalakkan Pembangunan Profesional & Sig. (2-hujung) & 0.000 \\
& N & 278 \\
Membangunkan Tanggungjawab Secara & Korelasi Pearson & $0.853^{* *}$ \\
Kolektif & Sig. (2-hujung) & 0.000 \\
Memastikan Persekitaran Pembelajaran & Korelasi Pearson & 278 \\
Yang Selamat Dan Teratur & Sig. (2-hujung) & $0.890^{* *}$ \\
& N & 0.000 \\
Penyediaan Sumber Secara Strategik & Korelasi Pearson & 278 \\
& Sig. (2-hujung) & $0.882^{* *}$ \\
& N & 0.000 \\
Menyelesaikan Masalah Kompleks & Korelasi Pearson & 278 \\
& Sig. (2-hujung) & $0.888^{* *}$ \\
& N & 0.000 \\
& Korelasi Pearson & 278 \\
& Sig. (2-hujung) & $0.855^{* *}$ \\
& N & 0.000 \\
\hline
\end{tabular}

** Korelasi adalah signifikan pada tahap 0.01 (2-hujung).

Analisis Korelasi Pearson dilancarkan untuk melihat hubungan antara dimensi-dimensi dalam amalan kepimpinan instruksional guru besar dengan komitmen guru sekolah rendah di daerah Beaufort di dalam jadual 12. Secara keseluruhannya, kesemua dimensi-dimensi iaitu dimensi merangka matlamat sekolah, memastikan pembelajaran berkualiti, menggalakkan pembangunan profesional, membangunkan tanggungjawab secara kolektif, memastikan persekitaran pembelajaran yang selamat dan teratur, penyediaan sumber secara strategik dan menyelesaikan masalah kompleks dengan komitmen guru mempunyai hubungan yang signifikan pada tahap yang sangat tinggi $(\mathrm{p}<0.01)$. Secara lebih terperinci, dimensi yang mempamerkan hubungan signifikan yang paling kuat adalah membangunkan tanggungjawab secara kolektif $(\mathrm{r}=0.890, \mathrm{p}=0.000)$, diikuti dengan dimensi penyediaan sumber secara strategik $(\mathrm{r}=0.888, \mathrm{p}=0.000)$. Seterusnya adalah dimensi memastikan persekitaran pembelajaran yang selamat dan teratur $(\mathrm{r}=0.882, \mathrm{p}=0.000)$ dan diikuti pula oleh dimensi menyelesaikan masalah kompleks $(\mathrm{r}=0.855, \mathrm{p}=0.000)$. Kemudian, dimensi kelima mencatat signifikan yang tinggi ialah menggalakkan pembangunan profesional $(\mathrm{r}=0.853, \mathrm{p}=0.000)$. Dimensi keenam pula ialah memastikan pembelajaran berkualiti $(\mathrm{r}=0.890, \mathrm{p}=0.000)$ dan dimensi terakhir ialah merangka matlamat sekolah $(\mathrm{r}=0.809, \mathrm{p}=0.000)$.

\section{Perbincangan Kajian}

Berdasarkan hasil dapatan kajian menunjukkan tahap amalan kepimpinan instruksional guru besar mengikut persepsi guru sekolah rendah di daerah Beaufort berada pada tahap yang tinggi. Keseluruhan 
konstruk-konstruk atau dimensi yang dikaji dalam amalan kepimpinan instruksional juga berada pada tahap yang tinggi. Dapatan kajian ini menunjukkan bahawa kesemua 54 orang guru besar di daerah Beaufort telah melaksanakan amalan kepimpinan instruksional dengan baik berdasarkan skor min setiap dimensi yang tinggi. Menurut pandangan guru-guru, guru besar banyak memberikan penumpuan kepada kepimpinan instruksional secara tidak langsung iaitu yang merangkumi tiga sub dimensi iaitu memastikan persekitaran yang selamat dan teratur, penyediaan sumber secara strategik dan menyelesaikan masalah kompleks berada pada tahap min yang tinggi berbanding kepimpinan instruksional secara langsung. Hasil penemuan ini selari dengan dapatan kajian Bendikson et al. (2012) yang mendapati pemimpin sekolah lebih cenderung ke arah kepimpinan instuksional secara tidak langsung. Namun, kajian tersebut melibatkan pengetua di sekolah menengah berbanding kajian ini yang berfokus kepada guru besar di sekolah rendah. Keadaan ini berlaku kerana pengetua bertindak sebagai fasilitator untuk aspek kepimpinan instruksional secara langsung. Peranan instruksional seperti sub dimensi memastikan pembelajaran yang berkualiti lebih banyak diambil alih oleh pemimpin pertengahan seperti penolong kanan, ketua bidang atau ketua panitia.

Keberkesanan amalan kepimpinan instruksional terbukti apabila guru besar dilihat mampu mengawal situasi dan membuat perubahan dalam pengurusan sekolah mereka. Ini selaras dengan pernyataan kajian mengenai gaya kepimpinan instruksional telah menjadi satu trend yang menjadi pilihan bagi negara-negara di rantau Asia yang menunjukkan peningkatan dan perkembangan yang positif (Hallinger et al., 2018; Dzulfida et al., 2020). Hasil kajian ini juga menyokong kepada kajian yang dilaksanakan oleh Davarajoo, E (2012) terhadap tahap kepimpinan pengajaran guru besar terhadap komitmen kerja dan kepuasan kerja guru di Zon Tanjung Karang, Selangor yang menunjukkan tahap kepimpinan yang tinggi. Begitu juga kajian yang dilakukan oleh Rozila dan Jamalul (2019) mengenai tahap kepimpinan instruksional pengetua terhadap komitmen 127 orang guru di Sekolah Berprestasi Tinggi (SBT) di daerah Seremban yang turut menunjukkan tahap kepimpinan instruksional yang sangat tinggi.

Dimensi yang mencatatkan skor min tertinggi adalah sub dimensi kelima iaitu memastikan persekitaran pembelajaran yang selamat dan teratur. Ini membuktikan guru besar di daerah Beaufort berjaya dalam memastikan persekitaran sekolah berada dalam keadaan yang selamat dan kondusif, mempunyai jalinan hubungan yang baik dengan ibu bapa dan masyarakat sekeliling serta senantiasa melibatkan mereka dengan aktiviti dan program di sekolah. Kebanyakan guru juga memilih 'sangat setuju' bahawa guru besar mengambil tindakan yang pantas dalam membaik pulih prasarana di sekolah mereka. Hasil dapatan kajian ini menyokong pernyataan daripada kajian Bellibas dan Liu, (2016) bahawa para penyelidik bidang pendidikan meningkatkan kajian yang mendalam terhadap iklim atau persekitaran sekolah dengan kepercayaan bahawa melakukan perubahan pada persekitaran sekolah sebagai satu cara untuk menambahbaikkan prestasi sekolah berdasarkan bukti apabila sekolah dipromosikan sebagai tempat yang lebih selamat dan boleh memberikan sokongan kepada organisasi didalamnya.

Penyelidikan tentang iklim sekolah yang menekankan betapa pentingnya suasana, budaya, sumber tenaga dan jaringan sosial sekolah mempunyai faktor-faktor yang penting yang lain seperti keselamatan, persekitaran sekolah, hubungan pengajaran dan pembelajaran dan proses penambahbaikan sekolah boleh mempengaruhi kemenjadian dan menambah pengalaman individu dalam sesebuah organisasi. (Loukas \& Murphy, 2007). Hasil kajian ini juga menyokong kajian Sinnu, C (2019) di Sekolah Rendah Agama Bantuan Kerajaan (SABK), Melaka menunjukkan tahap yang tinggi pada dimensi iklim sekolah iaitu perubahan yang dilakukan oleh pemimpin sekolah dalam membentuk persekitaran sekolah yang lebih kondusif memberi kesan yang lebih positif kepada kecemerlangan institusi pendidikan.

Sub dimensi yang mencatat min yang paling rendah dalam kajian ini adalah sub dimensi yang kedua iaitu memastikan pembelajaran berkualiti. Sub dimensi ini dikelompokkan dalam dimensi 2 iaitu kepimpinan instruksional secara langsung. Ini menunjukkan guru besar perlu memberikan penekanan yang lebih kepada menyusun atur program-program yang berkaitan dengan pengajaran akademik dan memastikan program kurikulum yang berterusan untuk memastikan proses pengajaran dan pembelajaran yang berkualiti. Dapatan kajian ini bertentangan dengan kajian daripada pengkaji- 
pengkaji seperti Murphy \& Shipman (2003) dan Hallinger (2003) mendapati bahawa cara yang terbaik untuk meningkatkan kaedah pembelajaran dan pengajaran yang lebih berkesan dengan memberikan tumpuan semula kepada pendekatan instruksional untuk mempengaruhi amalan baik seperti budaya pembelajaran di sekolah. Namun, dapatan kajian ini menyokong kajian Ali dan Mohammad (2017) yang mengkaji kepimpinan instruksional guru besar dan komitmen guru di Sekolah Kurang Murid (SKM) di Kapit. Walaupun guru besar dilihat mengamalkan kepimpinan instruksional yang tinggi, namun bukan salah satu faktor besar yang menyumbang kepada prestasi sekolah yang cemerlang.

Melalui dapatan kajian yang telah dianalisis, keempat-empat dimensi mempunyai skor min yang tinggi. Ini membawa maksud bahawa tahap komitmen guru sekolah rendah di daerah Beaufort adalah berada pada tahap yang tinggi. Secara perinciannya, dimensi komitmen guru yang berada pada kedudukan yang teratas adalah dimensi kedua iaitu kesediaan untuk mencapai matlamat yang mempunyai nilai min yang terendah. Guru-guru di sekolah rendah daerah Beaufort adalah komited dalam untuk menyumbangkan masa dan tenaga dalam mencapai matlamat. Mereka juga bersedia untuk memberikan kerjasama dalam meningkatkan mutu pendidikan di sekolah. Majoriti guru bersetuju bahawa mereka berusaha untuk mencari jalan penyelesaian bagi sebarang isu seperti masalah disiplin murid dan motivasi murid yang rendah. Komitmen guru terhadap murid bukan sahaja tertumpu kepada mengajar dan pencapaian akademik mereka tetapi juga perlu berhadapan dengan masalah tingkah laku, peribadi murid yang sensitif dan mengikuti perkembangan dan pencapaian murid (Thein et al., 2014). Secara keseluruhannya, kesemua ketujuh-tujuh sub dimensi dalam kepimpinan instruksional dalam teori ini mempengaruhi tahap amalan kepimpinan instruksional guru besar dengan hubungan positif yang kuat. Guru besar didapati cenderung mengamalkan aspek-aspek dalam dimensi (2) kepimpinan instruksional secara tidak langsung berbanding kepimpinan instruksional secara langsung yang turut mempengaruhi tahap komitmen guru.

\section{Implikasi Kajian}

\section{Implikasi Terhadap Teoritikal}

Kajian ini menggunakan gabungan Teori Kepimpinan Instruksional dan Model Kepimpinan Instruksional sebagai latar belakang untuk mengkaji tahap amalan kepimpinan instruksional guru besar. Dimensi kepimpinan instruksional secara tidak langsung yang merangkumi sub dimensi memastikan persekitaran pembelajaran yang selamat dan teratur, menyediakan sumber secara strategik dan menyelesaikan masalah kompleks menonjolkan kekuatan guru besar dalam menyediakan persekitaran yang baik untuk pengajaran. Dapatan ini menyokong Model Kepimpinan Intruksional Bendikson.

Kajian ini turut mengukuhkan Teori Komitmen Potter (1976) dan Model Komitmen Klein et.al (2014) yang menguji tahap komitmen guru. Keempat dimensi yang dikaji, dimensi (1) penerimaan matlamat dan nilai organisasi, dimensi (2) kesediaan mencapai matlamat, dimensi (3) keinginan untuk kekal dalam organisasi, dimensi (4) tahap komitmen dan dedikasi terhadap matlamat sekolah mempunyai hubungan positif dengan komitmen guru.

\section{Implikasi Terhadap Dasar}

Kementerian Pendidikan Malaysia (KPM) dapat memberikan penekanan yang lebih terperinci kepada pembangunan kepimpinan sekolah dengan menerapkan amalan kepimpinan instruksional dalam usaha untuk menambahbaikkan mutu pendidikan di Malaysia. Salah satu badan yang menggubal dasar ialah Jemaah Nazir dan Jaminan Kualiti (JNJK) yang bertanggungjawab menentukan piawaian yang lebih baik dalam Standard Kualiti Pendidikan Malaysia Gelombang 2, 2016 (SKPMg2). SKPMg2 digunakan sebagai panduan dalam memastikan kualiti pendidikan tercapai dan salah satu standard yang terkandung dalam SKPMg2 adalah memastikan kualiti kepimpinan yang berimpak tinggi. Tugas kepimpinan di sekolah sebagai peneraju, pembimbing dan pendorong yang jelas menerangkan ciri-ciri instruksional. Pihak KPM juga perlu memperhalus semula pengambilan calon-calon pengetua dan guru besar dengan menggariskan syarat kelayakan seperti pernah menghadiri latihan kepimpinan seperti kursus kepimpinan instruksional sebelum diterima menyertai program tersebut. 


\section{Implikasi Terhadap Amalan Guru Besar dan Guru}

Penguasaan dalam amalan kepimpinan instruksional sebagai salah satu gaya kepimpinan yang perlu dikuasai oleh seorang pemimpin sekolah. Sebagai pemimpin instruksional yang mantap, pentadbir dapat membuat perubahan yang lebih besar dan dinamik seiring dengan perubahan dan cabaran dalam bidang pendidikan zaman sekarang yang memerlukan kebijaksanaan dan kecekapan seorang pemimpin. Guru besar perlu mengaplikasikan gaya kepimpinan ini untuk mempengaruhi dan membimbing kakitangan bawahan yang kurang motivasi, tidak kompeten dan tidak berkemahiran. Namun, gaya kepimpinan ini tidak sesuai terhadap guru yang memahami peranan mereka dengan jelas, tahu bekerja, mempunyai kepuasan dalam bekerja dan mempunyai komitmen yang sangat tinggi (Nadia, 2019).

Implikasi terhadap guru sebagai nadi penggerak kepada kemajuan dan kecemerlangan sekolah. Kesediaan guru serta tahap komitmen dan dedikasi mereka untuk mencapai matlamat organisasi adalah tinggi dalam kajian ini. Walau bagaimanapun, keinginan guru untuk kekal di sekolah adalah yang paling rendah daripada keempat-empat sub dimensi dalam komitmen guru. Maka, nilai afektif guru perlu ditingkatkan untuk guru merasakan mereka adalah sebahagian daripada sekolah dan menganggap sekolah sebagai rumah yang kedua bagi mereka. Oleh itu, guru akan lebih bersedia dari segi mental, tenaga dan kemahiran untuk menyumbang kepada usaha meningkatkan kemajuan murid seterusnya menjadikan sekolah yang berkesan (Rosenholtz, 1989; Anderson, 1991; Muller, 1993).

\section{Implikasi Terhadap Kursus dan Latihan}

Amalan gaya kepimpinan ini dapat dimantapkan lagi dengan menambahbaikkan eleman-eleman yang telah dikenal pasti yang boleh membantu dalam pengurusan pentadbiran pendidikan. Bakal-bakal pemimpin sekolah perlu didedahkan dengan amalan kepimpinan instruksional dalam latihan kepimpinan (NPQEL) seperti yang dianjurkan oleh Institusi Aminuddin Baki (IAB). Pihak IAB dapat menambahbaik lagi standard kompetensi kepengetuaan dalam program latihan kepimpinan melalui dapatan hasil kajian ini melalui dimensi-dimensi yang telah dikenal pasti. Sumber rujukan dapatan daripada kajian ini dapat memberi tambahan input kepada aspek-aspek kepimpinan dalam latihan yang akan diberikan kepada bakal pemimpin sekolah. Pihak JPN dan PPD dapat merancang dengan lebih baik program atau kursus-kursus kepimpinan, pentadbiran dan pengurusan sekolah kepada semua pemimpin sekolah bukan sahaja kepada guru besar atau pengetua tetapi juga penolong-penolong kanan, ketua-ketua bidang dan ketua panitia. Pihak JPN dan PPD juga perlu memastikan setiap pemimpin sentiasa mengamalkan gaya kepimpinan yang berkesan kerana dapat membentuk iklim pentadbiran yang boleh mendorong ke arah kecemerlangan sekolah. Pemberian Anugerah Guru Besar Cemerlang juga harus mengambil kira aspek-aspek kepimpinan instruksional yang diamalkan oleh pemimpin sekolah memandangkan gaya kepimpinan ini menjurus ke arah mencapai kecemerlangan akademik sekolah.

\section{Kesimpulan}

Penguasaan dalam amalan kepimpinan instruksional sebagai salah satu gaya kepimpinan yang perlu dikuasai oleh seorang pemimpin sekolah. Sebagai pemimpin instruksional yang mantap, pentadbir dapat membuat perubahan yang lebih besar dan dinamik seiring dengan perubahan dan cabaran dalam bidang pendidikan zaman sekarang yang memerlukan kebijaksanaan dan kecekapan seorang pemimpin. Secara keseluruhannya, persepsi guru terhadap amalan kepimpinan instruksional guru besar berada pada tahap yang tinggi. Ini membuktikan guru besar mengamalkan kepimpinan instruksional dalam mengurus tadbir sekolah mereka. Kepimpinan instruksional guru besar secara langsung berfokus kepada meningkatkan pengajaran. Manakala, kepimpinan instruksional secara tidak langsung menumpu dalam menghasilkan persekitaran yang terbaik untuk sesi pengajaran dan pembelajaran. Namun kedua-dua dimensi dalam amalan kepimpinan instruksional mempengaruhi kesediaan, tahap komitmen dan dedikasi guru untuk mencapai matlamat. Amalan kepimpinan instruksional sebagai satu proses yang berterusan yang telah dibuktikan boleh mempengaruhi 
komitmen guru terhadap organisasinya sekaligus berkeupayaan untuk membudayakan dan meningkatkan tahap profesionalisme guru, meningkatkan prestasi kurikulum dan kualiti pembelajaran murid.

\section{Rujukan}

Ali Abdu \& Mohamed Yusoff Mohd Nor. (2017). Amalan Kepimpinan Instruksional Guru Besar dan Hubungannya Dengan Tahap Komitmen Guru Sekolah Pendalaman Daerah Kapit. Tesis Sarjana, Universiti Kebangsaan Malaysia.

Anderson, L.W. (1991). Increasing Teacher Effectiveness. UNESCO: International Institute for Educational Planning, Paris.

Andi Audryanah Md Noor. (2007). Kepimpinan Pengajaran dan Efikasi Kendiri Pengetua Sekolah Menengah dan Hubungannya dengan Pencapaian Akademik Sekolah. Tesis Sarjana. Fakulti Pendidikan, Universiti Teknologi Malaysia.

Aniza, B. \& Zaidatol Akmaliah, L.P. (2013). Amalan Kepimpinan Pengajaran Mengikut Prestasi Sekolah. In Seminar Pasca Siswazah Dalam Pendidikan (GREDUC) 2013: 346-353.

Bellibas, M.S. \& Liu.Y. (2016). The Effect of Principal's Perceived Intructional and Distributed Leadership Practices on Their Perceptions of School Climate. International Journal of Leadership in Education.

Bendikson, L., Robinson. V \& Hattie, J. (2012). Principals' Instructional Leadership and Secondary School Performance. Research Information for Teachers, 1, 2-8.

Colarelli, S.M \& Bishop, R.C. (1990). Career Commitment: Function, correlates, and management. Group and organizational studies, 15(2), 158-176.

Davarajoo, E. (2012). Perkaitan Antara Kepimpinan Pengajaran Guru Besar dengan Komitmen Kerja dan Kepuasan Kerja Guru Sekolah Rendah di Zon Tanjung Karang. Kertas Final. Seminar Nasional Pengurusan dan Kepimpinan Pendidikan ke -19.

Downs, C.W., Clampitt, P. \& Pfeiffer, A. (1998). Communication and Organizational Outcomes in G. Goldhaber and G. Barnett (eds). Handbook of Organizational Communication, Norwood:171211.

Dzulfida A. Razak, Muhammad Nasri Md Hussain \& Abdullah Abdul Ghani. (2020). Amalan Kepimpinan Instruksional Pengetua dan Hubungannya Dengan Komitmen Organisasi di Sekolah Menengah Agama Swasta. Journal of Islamic, Social, Economics and Development (JISED) $5(28), 8-24$.

Gurr-Mark, D., Drysdale-George, L. \& Mulford, B. (2010). Australian Principallnstructional Leadership: Direct and Indirect Influence. Magis, Revista Internacional de Investigacion en Education, 2(4), 299-314.

Hackney, C. (2012). Personality, Organizational Commitment and Job Search Behaviour: A Field Study. Tesis Dr Fal, University of Tennessee.

Haji Mohd Noor Jaafar. (2004). Kepimpinan Pengajaran Guru Besar, Komitmen Guru dan Kepuasan Kerja Guru: Satu Kajian Perbandingan dan Hubungan Antara Sekolah Berkesan dengan Sekolah Kurang Berkesan. Tesis Dr Fal, Universiti Sains Malaysia.

Hallinger, P. (2000). A Review of Two Decades of Research on the Principalship Using the Principal Intructional Management Rating Scale.

Hallinger, P. (2003). Leading Educational Change: Reflections on the Practice of Instructional and Transformational Leadership. Cambridge Journal of Education, 33(3), 329-351.

Hallinger, P., Adams, D., Harris, A. \& Jones, M.S. (2018). Review of Conceptual Models and Methodologies in Research on Principal Intructional Leadership in Malaysia: A Case of Knowledge Construction in a Developing Society. Journal of Educational Administration, 56(1), 104-126.

Hallinger, P. \& Heck, R.H. (1996). Ressessing the Principal's Role in School Effectiveness: A Review of Empirical Research, 1980-1995. Educational Administration Quarterly, 32(1).

Hassenpflug, A. (2013). How to Improve Instructional Leadership: High School Principal Selection Process Versus Evaluation Process. Journal of Educational Strategies, Issues, and Ideas, 86(3), 90-92. 
Kementerian Pelajaran Malaysia. (2007). Memperkasa Kepimpinan Instruksional Di Sekolah. Bahagian Sekolah. Kementerian Pelajaran Malaysia.

Klein, H.J., Cooper, J.T., Molloy, J.C. \& Swanson, J.A. (2014). The Assessment of Commitment: Advantages of A Unidimensional, Target- Free Approach. Journal of Applied Psychology, 99(2), 222-238.

Loukas, A. \& Murphy, J.L (2007). Middle School Student Perceptions of School Climate: Examining Protective Functions on Subsequent Adjustment Problems. Journal of School Psychology, 45, 293-309.

Lokman Mohd Tahir, Al Muzammil, M. \& Mislina Salleh. (2013). Impak Strategi Politik Terhadap Amalan Kepimpinan Pengajaran Pengetua Cemerlang. Jurnal Teknologi Sains Sosial, 60(1).

Mathieu, J.E. \& Zajac, D.M. (1990). A Review and Meta-Analysis of the Antecedents, Correlates and Consequences of Organizational Commitment. Psychological Bulletin, 108, 171-188.

Mohammad Sani Ibrahim \& Mohd Izham Mohd Hamzah. (2012). Pengurusan Perubahan Makro Dalam Pendidikan. Bangi: Penerbit Universiti Kebangsaan Malaysia.

Mohd Yusri Ibrahim. (2012). Model Kepimpinan Pengajaran Pengetua, Efikasi dan Kompetensi Pengajaran. Tesis Dr Fal, Universiti Malaysia Terengganu.

Muller. (1993). Parent Involvement and Academic Achievement: An Analysis of Family Resource Available to The Child. In B. Scheneider and J.S Coleman, Parents, Their Children and School :77.

Murphy, J.F., Hallinger, P., Mitman, A. \& Weil, M. (1984). Academic Press: Translating High Expectations in School Policies and Classroom Practice. Educational Leadership, 40(3), 22-26.

Nadia K. (2019). The Impact of Organizational Climate on Teachers Commitment. Journal of Education and Educational Development, 6(2), 327-342.

Nor Azni Abdul Aziz. 2015. Hubungan Antara Kepimpinan Instruksional Pengetua dengan Komitmen Untuk Perubahan Guru Sebagai Mediator dalam Melaksanakan Pentaksiran Berasaskan Sekolah. Tesis Dr Fal, Universiti Pertanian Malaysia.

Noorshazrina Faustine \& Mohd Izham Mohd Hamzah. (2016). Amalan Kepimpinan Instruksional Guru Besar dan Hubungannya Terhadap Komitmen Kerja Guru Sekolah Rendah di Daerah Lawas, Tesis Sarjana, Universiti Kebangsaan Malaysia.

Nurharani S., Norshidah N. \& Afni Anida A. (2013). Rekindle Teacher's OrganizationalCommitment: The Effect of Transformational Leadership Behavior. Procedia Social and Behavioral Sciences 90, 566-574.

Putri Anggun S., Wahyu PH, R., Arnaningsih., Y \& Agustine, A. (2016). Kepimpinan Pendidikan. Makalah Kepimpinan Pendidikan.

Robbins, S.P. \& Thimoty, A.J. (2008). Perilaku Organisasi. Edisi 12. Buku 1.

Rosenholtz, S.J. (1989). Teachers' Workplace: The Social Organization of School. New York: Longman.

Rozila Md Yusof \& Jamalul Lail Abdul Wahab. (2019). Kepimpinan Instruksional Pengetua dan Hubungannya dengan Komitmen Guru di Sekolah Berprestasi Tinggi (SBT) di Daerah Seremban. International Journal of Education, Psychology and Counseling, 4(33), 107-121.

Sinnu, C. (2019). Hubungan Instruksional Guru Besar dengan Komitmen kerja Guru SekolahAgama Bantuan Kerajaan (Sekolah Rendah) Di Negeri Melaka. Jurnal Ilmi 9, 1-14.

Tarakol, M. \& Rennick, R. (2011). Making Sense of Cronbach's Alpha. International Journal of Medical Education, 2, 53-55.

Thein, L.M., Nordin Abdul Razak \& Ramayah, T. (2014). Validating Teacher Commitment Scale Using a Malaysian Sample. Sage Open. April-June: 1-9.

Walker, A. (2015). Clones, Drones and Dragons: Ongoing Uncertainties Around School Leader Development. School Leadership and Management, 53(4), 554-570.

Weber, J. (1996). Leading the Instructional Programme in Smith SC Piele PK (eds) School Leadership: Handbook for Excellence in Student Learning. USA: ERIC Clearinghouse on Educational Management.

Wildy, H. \& Dimmock, C. (1993). Instructional Leadership in Primary and Secondary School in Western Australia. Journal of Educational Administration, 31(2), 43 -62. 